\title{
A Preliminary Study of the Sustainability of Oil Palm Biomass as Feedstock: Performance and Challenges of the Gasification Technology in Malaysia
}

https://doi.org/10.15255/KUI.2020.077 KUI-51/2021

Review

Received December 1, 2020

Accepted January 25, 2021

\author{
M. S. M. Zaini $\mathrm{a}^{*}$ and M. J. Jalil ${ }^{b}$ \\ a School of Chemical Engineering, College of Engineering, Universiti Teknologi MARA, \\ Cawangan Terengganu, Kampus Bukit Besi, 23200 Dungun, Terengganu, Malaysia \\ bSchool of Chemical Engineering, College of Engineering, Universiti Teknologi MARA, \\ Cawangan Pulau Pinang, 13500 Permatang Pauh, Pulau Pinang, Malaysia
}

This work is licensed under a Creative Commons Attribution 4.0 International License

\begin{abstract}
The excessive energy utilisation worldwide has prompted awareness of finding a new clean energy. Malaysia has large oil palm resources and releases huge amounts of oil palm biomass. Since oil palm biomass is abundantly available in Malaysia, it has the high potential of being utilised as fuel for gasification technology. Although many institutions in Malaysia are undertaking numerous research activities, the gasification technologies are not progressing as expected. The understanding of the potential and challenges faced by Malaysian industries are vital to evaluate the feasibility of gasification technology using oil palm biomass in Malaysia.
\end{abstract}

\section{Keywords}

Greenhouse gases, oil palm biomass, sustainability, challenge, gasification technology, energy conversion

\section{Introduction}

The increased demand in energy utilisation worldwide has prompted awareness of the possible depletion of fossil fuel sources. The use of fossil fuel as a primary source of energy generation, powering transportation, machinery, etc., has led to excessive emission of $\mathrm{CO}_{2}$ gas. ${ }^{1}$ Fossil fuel is abundantly available in Malaysia; the energy from the burning of fossil fuel is believed to be one of the main causes that threaten the sustainability of the ecosystem, thus creating many environmental problems. One of the detrimental effects is the emission of huge amounts of greenhouse gases, such as $\mathrm{CO}_{2}, \mathrm{NO}_{x}$ and $\mathrm{SO}_{x}$ into the atmosphere. Among the greenhouse gases, mostly $\mathrm{CO}_{2}$ is being released into the environment. Fig. 1 shows the emission of $\mathrm{CO}_{2}$ in $\mathrm{Ma}$ laysia, and it is expected to increase every year, as reported in BP Statistical Review of World Energy. ${ }^{2}$

The graph revealed that $\mathrm{CO}_{2}$ emission in Malaysia had increased significantly from 183.3 million metric tonnes in 2006 to 263.8 in 2016, and is predicted to increase up to 400 million tons if no action is taken. ${ }^{3}$ Furthermore, $\mathrm{CO}_{2}$ emissions will inevitably continue to increase as long as fossil fuel is used as the primary power source. ${ }^{4}$ Power generation from the coal power plant emits high concentrations of $\mathrm{CO}_{2}$ gas mainly due to the composition of coal with high carbon content. As a result, the combustion of coal emits a large amount of $\mathrm{CO}_{2}$ and $\mathrm{SO}_{x}$ that create acid rain and other pollution. Environmentally, from a landscape point of view, the mining of coal may lead to the destruction of land and destroy the sustainability of natural resources. ${ }^{5}$

* Corresponding author: Mohd Saufi Md Zaini,

Email: saufizaini@uitm.edu.my

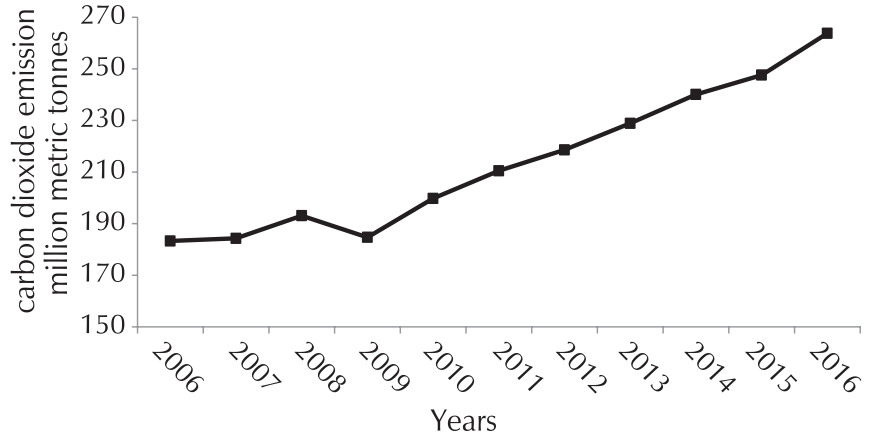

Fig. 1 - Carbon dioxide emission in Malaysia

The Kyoto Protocol was established in December 1997 in Kyoto, Japan, to monitor and control the emission of greenhouse gases worldwide. Under the Kyoto Protocol, the industrial countries had agreed and committed to reduce by 2012 their emissions of greenhouse gases by $5.2 \%$ relative to the 1990 emission. ${ }^{6}$ The aim of the conference was to reduce and eliminate six primary greenhouse gases, which are methane $\left(\mathrm{CH}_{4}\right)$, carbon dioxide $\left(\mathrm{CO}_{2}\right)$, sulphur hexafluoride $\left(\mathrm{SF}_{6}\right)$, nitrous oxide $\left(\mathrm{N}_{2} \mathrm{O}\right)$, hydrofluorocarbon, and perfluorocarbons. ${ }^{6}$ Many countries, including Malaysia, are now taking serious action to accomplish the aims by reducing dependency on fossil fuels.

Malaysia encounters crucial challenges when dealing with power generation due to sustainability issues. This is vital for security of supply and ensuring the consistency of various energy resources. Therefore, there is a necessity to find new energy sources to compensate the energy supply, demand, and reserves in Malaysia. To this end, it is impor- 


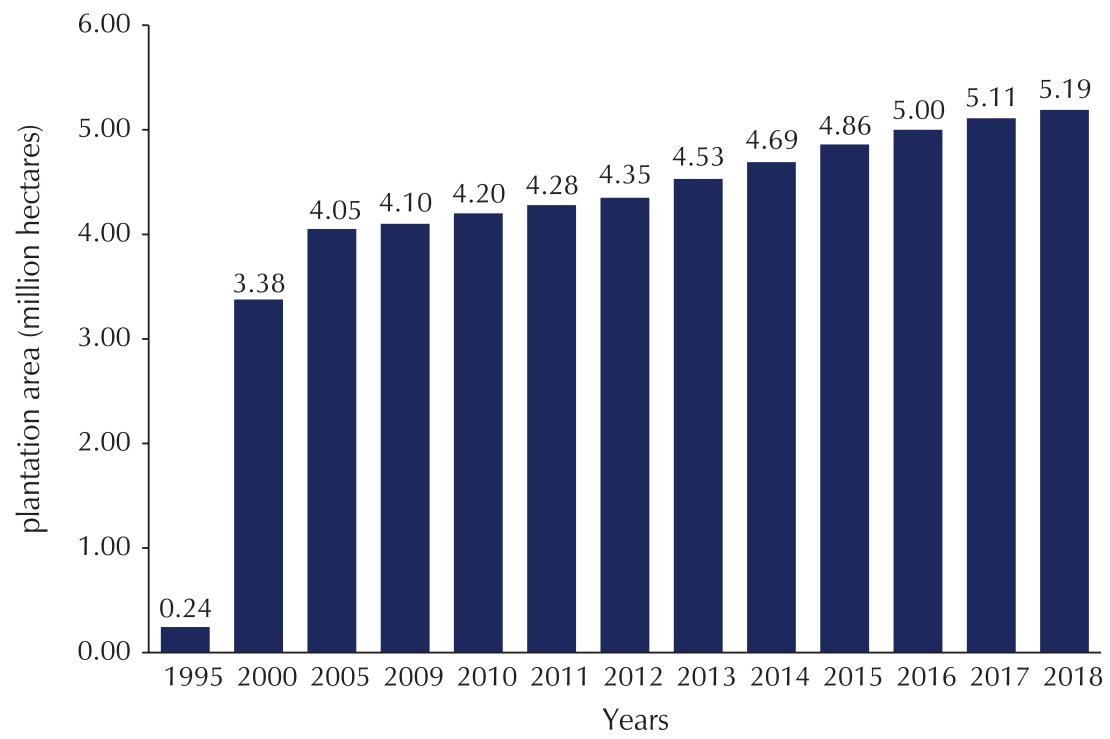

Fig. 2 - Area of oil palm plantation in Malaysia ${ }^{7}$

tant to develop appropriate strategies for utilising renewable feedstock, such as the energy from biomass. This paper aimed to review the recent research on the potentiality of using oil palm biomass as feedstock for thermochemical conversion technology, mainly gasification technology, as well as the challenges faced by the Malaysian industries to commercialise the energy from biomass.

\section{Oil palm biomass}

\subsection{Oil palm biomass feedstock in Malaysia}

Malaysia is blessed with plenty of natural resources such as oil palm. It is one of the major economic crops in Malaysia, and contributes to about $43 \%$ of the world production, while Malaysia has become the second largest exporter of oil palm in the world after Indonesia. According to Malaysian Palm Oil Council (2008), ${ }^{7}$ the global production of oil palm in Malaysia has increased since it was first introduced in Malaya (name before Malaysia) until the present date. The plantation area increased tremendously from 2.4 million hectares in 1995 to 5.19 million hectares in 2018 (Fig. 2). The increased areas of plantation reflect the production of oil palm as well. Until 2018, oil palm production has achieved 1.43 million tons, which is $300 \%$ more than that in 1960 .

Despite high economic returns to the country, the industry of palm oil also releases enormous amounts of waste. The oil extracted from the fresh fruit bunch in the oil mill leaves unwanted residue, such as empty fruit bunches (EFBs), mesocarp, palm press fibre (PPF), palm kernel shell (PKS), and palm oil mill effluent (POME). ${ }^{8}$ According to Shuit et al., ${ }^{9}$ about $50-70$ t of biomass residue can be generated on one hectare of oil palm plantation daily. In 2009, the palm oil industries generated over 60 million of oil palm biomass and the amount of biomass keeps increasing constantly. The study by Prasertsan et al..$^{10}$ showed that the waste generated by palm oil mills was around $1.18 \cdot 10^{6} \mathrm{~m}^{3}$ every year, which EFB, PPF, and PKS accounted for about $28 \%$, $12 \%$, and $8 \%$, respectively. Recently, in 2019, over 83 million tons of oil palm biomass were produced and from this amount, it is estimated that oil palm biomass consists of 21.8 million tons of oil palm fronds, 6.4 million tons of $\mathrm{EFB}$, and 10.6 million tons of palm fibre and palm kernel shell. ${ }^{11}$

Fig. 3 illustrates the residual biomass pathway generated from the processes of palm oil extraction in the palm oil mill. Based on the figure, the "green" products are the commercialised products, while the "red" products remain as waste. It is estimated that only $49 \%$ of fresh fruit bunches are considered as the main product, which consists of $43 \%$ of crude oil, and $6 \%$ of kernel, while $51 \%$ is regarded as waste. ${ }^{12}$

Based on the previous data, it is clear that EFBs, PPF, PKS and POME are the major waste produced from palm oil mill. The massive production of palm oil waste creates huge potential for energy conversion or production of high value-added-products, considering their costs, properties, and environmental friendliness. In addition, the conversion of palm oil waste into energy would support the national agenda under the National Biomass Strategy 2020 and National Key Economic Areas 2013. ${ }^{13}$

\subsection{Sustainability of oil palm biomass}

The concept of sustainable plantation practices for all agriculture crops, including oil palm industry, must meet the criteria prescribed by Rio Earth Summit in 1990, which states that all plantations must follow the $3 \mathrm{P}^{\prime} \mathrm{s}$, which is Profit, People, and Planet. This is crucial in order to conserve a good and healthy environment. ${ }^{14}$

Recently, there was an accusation made by NGOs claiming that global warming is caused by the destruction of forest due to oil palm cultivations. Deforestation may lead to destruction and erosion of biodiversity. Nevertheless, the Ma- 


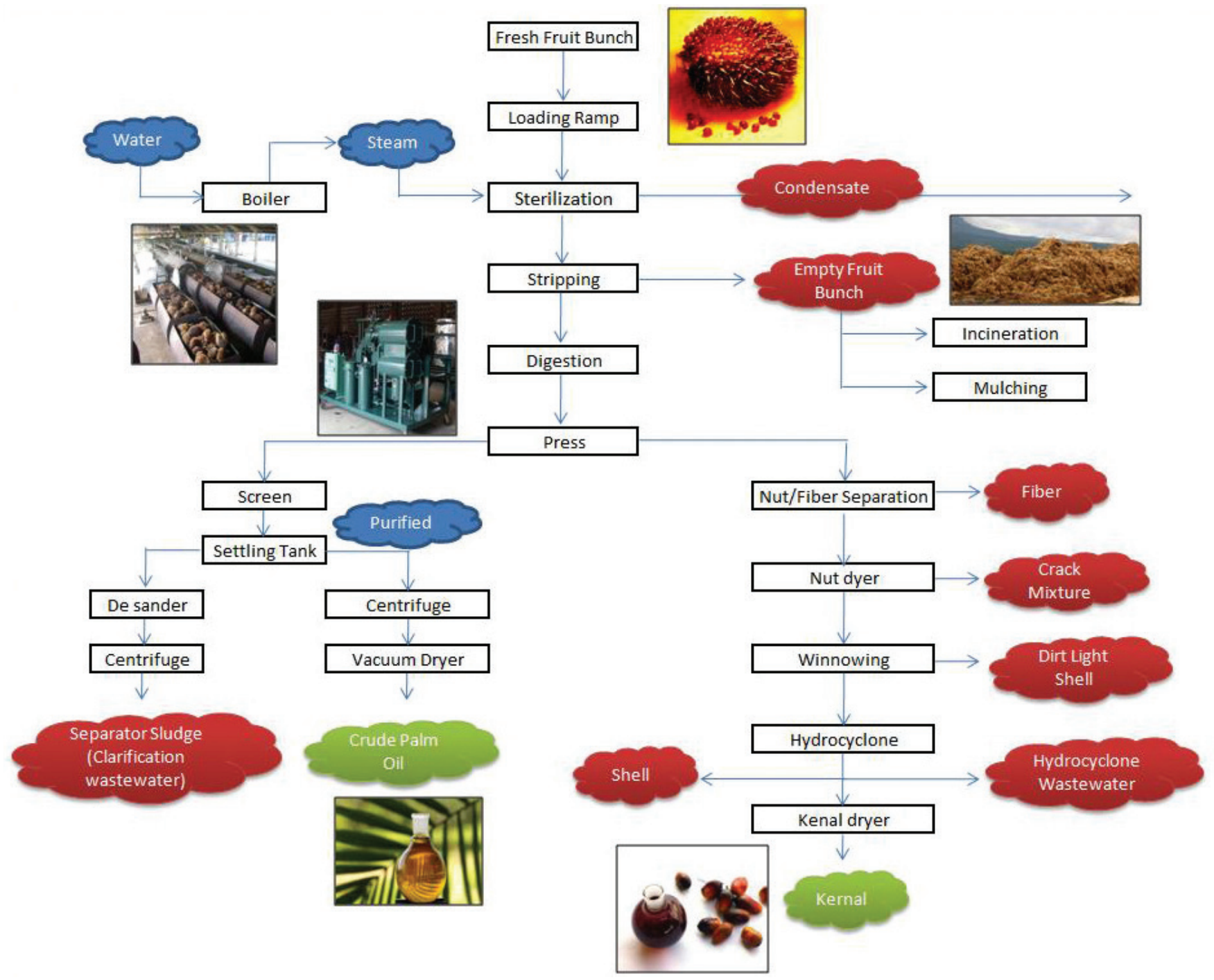

Fig. 3 - Processes of palm oil extraction

laysia government addressed all of the claims. According to Malaysia palm oil council (2011), ${ }^{7}$ oil palm accounts for only $0.22 \%$ of the world agricultural land. In addition, the main contributor to the climate change is the use of fossil fuel, which accounts for $57 \%$ as compared to the emission from the agriculture sector, which only contributes $17 \%$ of the total global greenhouse gas emissions, as shown in Fig. 4.

Thus, oil palm cultivation releases only $0.22 \% \times 17 \%$ of the total or $0.0374 \%$ of the global greenhouse gas emissions. With this small amount of emission, there is no clear evidence for blaming oil palm as a significant contributor to global warming.

In order to preserve the sustainability of palm oil, a Round Table on Sustainable Palm Oil (RSPO) was established with the aim of enhancing utilisation of sustainable oil palm products through credible global standards. RSPO is responsible for sustainable palm oil production, i.e., that it is economically viable, environmentally appropriate, socially beneficial, best agriculture practice, continuous improvement, new planting technology, good management and

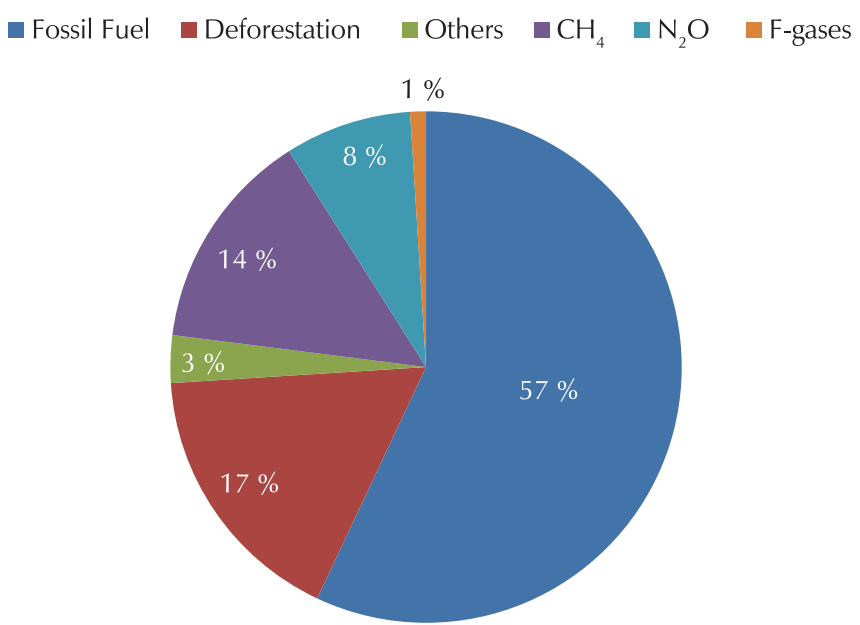

Fig. 4 - Main contributor activities to climate change

operation. ${ }^{9}$ RSPO will ensure the challenge of conserving the land for forest with high conservation value as the major objective. 
Carbon balance of oil palm biomass utilisation is an important indication of the sustainability of oil palm biomass. Instead of burning fossil fuel to generate energy, oil palm biomass combustion is much cleaner and carbon-free. This is because the carbon, which is released into the atmosphere, will be assimilated during the plant growth (Fig. 5). Moreover, oil palm biomass does not contribute to net amount of carbon due to the positive carbon sequestering effect of the oil palm trees. Nevertheless, oil palm biomass is one type of waste, thus using the waste to generate electricity or biofuel can reduce the dependency on fossil fuel.

The utilisation of oil palm biomass from oil palm industry leads to social sustainability by creating more and better jobs, especially for Malaysians. Under the National Biomass Strategy 2020 and National Key Economic Area, the Malaysian government initiated several collaborations with private sector companies, as well as domestic and international research institutes and academia to assess the potential of gaining more revenue from its palm oil industry through utilisation of associated biomass. ${ }^{15}$ To accomplish these missions, many parties have to play their role by contributing their specialty in their specific areas. For example, the labour requirement is relatively high, especially for the cultivation of energy crops, transportation, harvesting, etc. On the other hand, many scientists are needed for research and development on sustainability and environmental aspects. Finally yet importantly, many engineers are required, especially in the technical areas, such as computer application, teaching, managing and training, technical sales, marketing, designing of process plan \& equipment. Under the National Key Economic Area, in 2021, it is expected that the palm oil industry could provide 41600 new local jobs upstream 81800 additional jobs downstream, $40 \%$ of which are highly skilled jobs. ${ }^{16}$

\subsection{Research and development on oil palm biomass}

With the large amount of biomass being dumped daily in the oil palm industry, it is wasteful if the biomass is not used properly. Due to good characteristics of palm oil biomass (Table 1), many studies have been conducted on the potential of converting the waste into value-added products.

Table 1 -Chemical and physical properties of palm oil biomass $^{17,18}$

\begin{tabular}{l|c|c|c|c}
\hline \multicolumn{5}{c}{ Chemical properties } \\
\hline & EFB & Frond & Trunk & Shell \\
\hline holocellulose $\%$ & $68-86$ & $80-83$ & $42-45$ & $40-47$ \\
\hline cellulose $\%$ c $\%$ & $43-65$ & $40-50$ & $29-37$ & $27-35$ \\
\hline hemicellulose/\% & $17-33$ & $34-38$ & $12-17$ & $15-19$ \\
\hline lignin/\% & $13-37$ & $20-21$ & $18-23$ & $48-55$ \\
\hline ash/\% & $1-6$ & $2-3$ & $2-3$ & $1-4$ \\
\hline \multicolumn{4}{|c|}{ Physical properties } \\
\hline density/g cm ${ }^{-3}$ & $0.7-1.55$ & - & 1.1 & 1.28 \\
\hline tensile strength/MPa & $0.1-0.4$ & 71 & $300-600$ & 20 \\
\hline young modulus/GPA & $1-9$ & 1.7 & $15-32$ & 8.5 \\
\hline elongation break/\% & $8-18$ & 11 & - & 2.75 \\
\hline
\end{tabular}

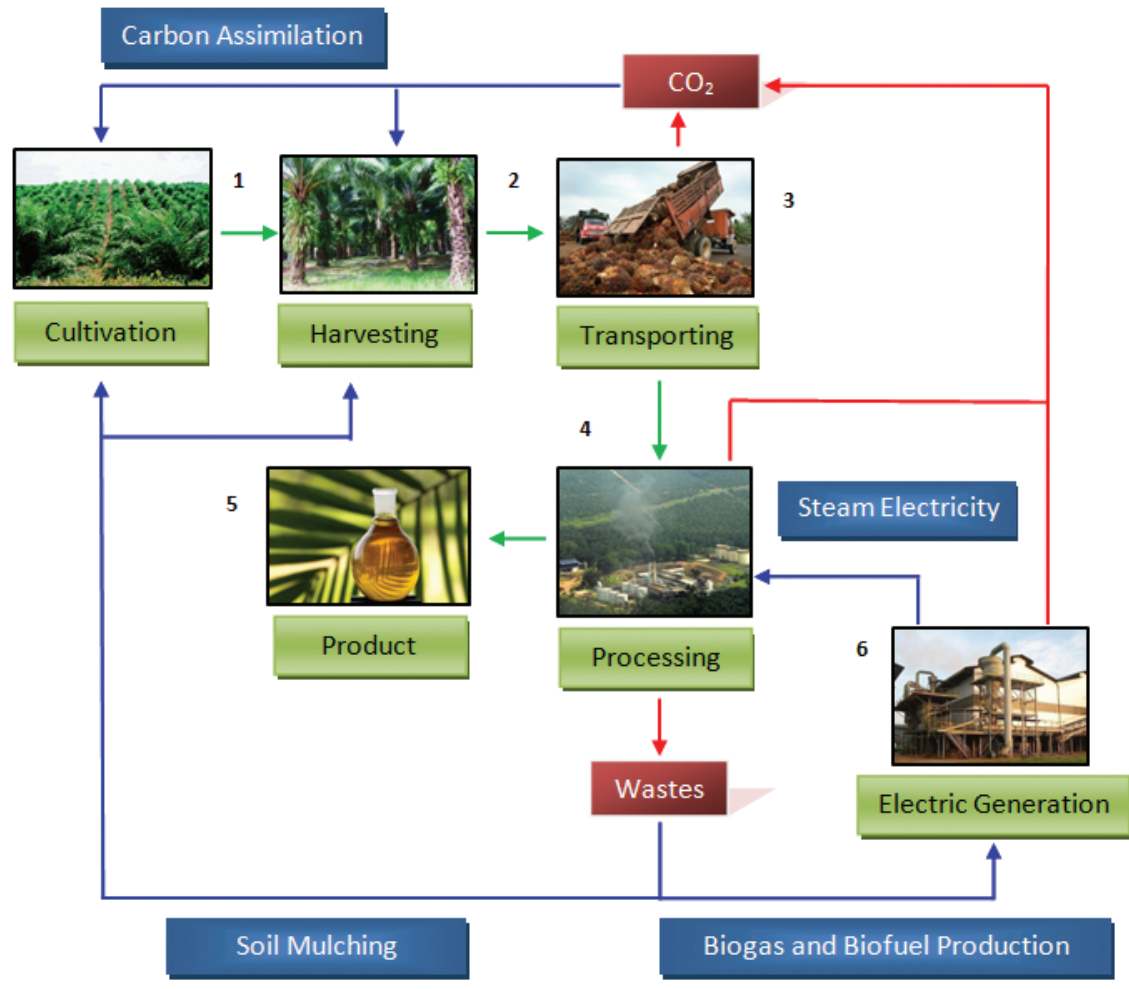

Fig. 5 - Carbon balance of oil palm biomass 
Table 2 - Previous study on the conversion of oil palm biomass into other products

\begin{tabular}{c|c|c}
\hline Oil palm biomass & Mode of conversion & Products \\
\hline Empty fruit bunch, kernel & Physical and thermal & Briquettes \\
\hline Fronds & Physical and thermal & Particleboard composite panels \\
\hline Trunks, empty fruit bunches & Physical and thermal & Hybrid plywood \\
\hline Fibre, empty fruit bunch, kernel shell & Chemical & Biodegradable plastics (polyhydroxyalkanoates) \\
\hline Empty fruit bunches & Thermochemical & Polymer bio-composite \\
\hline Fronds & Chemical & Animal feed \\
\hline Fronds & Chemical & Biodegradable film \\
\hline Trunks, Fronds, empty fruit bunch, leaves & Thermal & Adsorbent \\
\hline Fronds, empty fruit bunches & Hydrothermal & Cellulose inhibitor \\
\hline Trunks, fronds, empty fruit bunches & Biochemical & Vermicompost \\
\hline
\end{tabular}

Oil palm fronds are produced throughout the year during harvesting of the fresh fruit bunch and pruning of the palm trees. The study by Abu et al. ${ }^{19}$ revealed that oil palm fronds are one of the sources of roughage for ruminant. Oil palm fronds are classified as fibrous crop residue, thus they can be used as a feed for animals, such as beef, cattle, and cow. The authors also conducted a feeding test by feeding lactating dairy cows with chopped oil palm fronds mixed with $70 \%$ concentrates based on palm kernel cake into pieces. The cows produced milk more efficiently without harmful effects on the animals' health or milk flavour. On the other hand, a review by Shuit et al. ${ }^{9}$ showed that the fronds from oil palm trees can be converted into pulp based on the fibrous crop characteristics. However, the production of pulp remains under research stage. According to Sulaiman et al., ${ }^{20}$ oil palm fronds contain a high amount of cellulose and sugar, especially at the basal part, making it suitable for the production of biofuels and bio-based.

Oil palm trunk fibre can be utilised as a concrete reinforcement. Research by Z. Ahamd ${ }^{21}$ showed that fibre from oil palm trunk has high tensile strength (300-600 $\mathrm{N} \mathrm{mm}^{-2}$ ) with high density $\left(1200 \mathrm{~kg} \mathrm{~mm}^{-3}\right)$. The high density of fibre with high lignin content $(23.03 \%)$ shows their strength is better than other natural fibres. This was clearly proved by the author after he succeeded in improving the mechanical properties and durability of concrete by adding $1 \%$ of oil palm trunk fibre into concrete which played the role as a crack arrester. The oil palm trunk fibre also acts as a chemical resistant, especially to $\mathrm{NaOH}$ and $\mathrm{NaCl}$.

Extensive research has been carried out on the sustainable disposal of empty fruit bunches (EFBs). An investigation by Baharuddin et al. ${ }^{8}$ showed that vermicomposting of pressed shredded EFBs is more effective compared to that of non-shredded EFB. Pressed shredded EFBs are smaller, thus increasing surface area, which is an important parameter to ensure an efficient microbial consumption process. The author believes that co-composting, i.e., mixing pressed shredded EFB and POME under anaerobic sludge and open system would be beneficial to vermicomposting. POME tends to accelerate the EFB composting, thus the combination of both substances comprises a considerable amount of nutrients with low concentration of heavy met- als suitable as fertilisers and soil amendments. On the other hand, EFB can also be converted into pulp. EFB is regarded as lignocellulose residue, and therefore converting EFB into pulp and paper would be beneficial, especially for profit. In Malaysia, the first pulp and paper made from oil palm biomass was established in Sabah by Forest Institute of Malaysia (FRIM) in collaboration with Borneo Advanced Sdn. Bhd. Using the caustic soda technology, FRIM was able to generate one tonne of pulp in every 5 tonnes of EFB. ${ }^{9}$ The EFB pulp exhibits lower tensile strength but higher tearing resistance. $^{22}$

Crude palm oil is like other vegetable oil; it can be used as a boiler fuel to generate heat and electricity. The crude palm oil is in liquid form and easily burned. In Europe, crude palm oil was blended with petroleum diesel to form a new product known as biodiesel. The majority of transportation manufacturers limit the proportion to $15 \%$ of blended biodiesel. Biodiesel from crude palm oil produces cleaner energy, less carbon dioxide emission, low black smoke of carbon particulates, carbon monoxide, and sulphur dioxide. ${ }^{23}$

Much other research has been devoted to converting oil palm biomass into value-added-products. The application of oil palm biomass in different sectors is shown in Table 2.

\section{Best management practice}

The development of best management practices for oil palm plantation has been driven by the awareness of the importance to take care of the environment and, at the same time, the ability to enhance the overall productivity of the operations. All companies and NGOs are involved in the sustainable production of palm oil in an environmentally responsible manner.

Starting from the cultivation of oil palm to the production of energy, it must be carried out with a better approach and a good quality management practice. These practices must be environmentally friendly approaches, such as zero burning approach, which avoids the burning of forests and clearing as inappropriate activities for land preparation. ${ }^{34}$ 
Beside using agrochemicals like pesticides or herbicides for pest control and plant protection, most oil palm plantations have switched to a technique using natural ecosystem like barn owls to control the population of rats that contribute to the destruction of oil palm trees. ${ }^{35}$ This technique is much simpler, inexpensive, and effective without harming the environment and the plants.

The lack of consistency in implementing best management practices will cause massive deforestation, natural biodiversity destruction, pollution emission, etc. All these practices are to ensure that oil palm plantations are safe and environmentally sustainable for the long-term, as well as economically and financially viable.

\section{Energy from oil palm biomass}

\subsection{Thermochemical conversion technology}

The energy from biomass can be exploited through a thermochemical process. Thermochemical conversion is the process that thermally converts biomass into gaseous, solid, and/or liquid fuel. Generally, there are three main thermochemical conversion technologies, which are combustion, pyrolysis, and gasification. Table 3 summarises the oil palm biomass energy conversion technology studied by previous researchers.

Table 3 - Previous studies of conversion technology of oil palm biomass

\begin{tabular}{|c|c|c|c|}
\hline $\begin{array}{c}\text { Thermochemical } \\
\text { conversion }\end{array}$ & Oil palm biomass & Product & Refs. \\
\hline Combustion & $\begin{array}{c}\text { Kernel shell } \\
\text { Empty fruit bunch } \\
\text { Fibre }\end{array}$ & $\begin{array}{c}\text { Heat } \\
\text { Fuel } \\
\text { Energy } \\
\text { Electricity }\end{array}$ & $36-40$ \\
\hline Pyrolysis & \begin{tabular}{|c|} 
Kernel shell \\
Empty fruit bunch \\
Fibre \\
Trunk
\end{tabular} & \begin{tabular}{|c|} 
Bio-oil \\
Bio-char \\
Producer gas \\
Char
\end{tabular} & $41-45$ \\
\hline Gasification & $\begin{array}{c}\text { Kernel shell } \\
\text { Empty fruit bunch } \\
\text { Fibre }\end{array}$ & $\begin{array}{c}\text { Heat } \\
\text { Fuel (syn-gas) } \\
\text { Energy } \\
\text { Activated carbon }\end{array}$ & $46-49$ \\
\hline
\end{tabular}

Combustion is a process to convert the chemical energy stored in biomass into heat, gas, electricity, and mechanical power. Typical waste management practices of palm oil mill in Malaysia recycle the oil palm biomass, such as EFB, kernel shell, and mesocarp fibre, for production of steam based on a combustion process. However, because it has a high moisture content (Table 4) ${ }^{49}$ some of this biomass has to be treated prior to burning it in the boiler. Physical treatment process is also required to increase the effectiveness of use as a fuel, such as drying to reduce the moisture content, and shredding to reduce the size of EFB. In order to generate electricity from combustion process, the facto- ry must have a combustion unit consisting of boiler and/or furnace, steam turbine and generator.

Table 4 - Chemical properties and calorific content of oil palm biomass

\begin{tabular}{c|c|c|c|c|r}
\hline \multirow{2}{*}{$\begin{array}{c}\text { Biomass } \\
\text { type }\end{array}$} & $\begin{array}{c}\text { Calorific } \\
\text { value } \\
\mathrm{kJ} \mathrm{kh}^{-1}\end{array}$ & $\begin{array}{c}\text { Moisture } \\
\text { content } \%\end{array}$ & \multicolumn{3}{|c}{ Proximate analysis $\%$} \\
\cline { 5 - 7 } & $\begin{array}{c}\text { Volatile } \\
\text { matter }\end{array}$ & Ash & $\begin{array}{c}\text { Fixed } \\
\text { carbon }\end{array}$ \\
\hline $\begin{array}{c}\text { Empty fruit } \\
\text { bunch }\end{array}$ & 18795 & 65 & 87.1 & 4.6 & 8.4 \\
\hline Fibre & 19055 & 42 & 84.9 & 6.1 & 9.0 \\
\hline Shell & 20093 & 17 & 83.5 & 3.0 & 13.5 \\
\hline Trunk & 17471 & 76 & 86.7 & 3.4 & 9.9 \\
\hline Frond & 15719 & 71 & 85.1 & 3.4 & 11.5 \\
\hline
\end{tabular}

Pyrolysis is an efficient process to convert oil palm biomass into bio-char, bio-oil, and non-condensable gases (Eq. 1). The process is typically operated at high temperatures without the presence of oxygen. Pyrolysis consists of exothermic and endothermic reactions. Through pyrolysis process, hydrocarbon molecules of oil palm biomass are decomposed into smaller components. Due to the highly oxygenated component and conveniently broken down, hemicellulose is the first component to decompose producing organic acids, acetic acid, furans, and sugar. As temperature is elevated, cellulose begins to decompose producing levoglucosan and other anhydrocelluloses, and finally lignin degraded into other smaller molecules of polysubstituted phenols and oligomers. ${ }^{45}$ The main product of pyrolysis is bio-oil, and potentially it can be used as fuel or chemical feedstock. Furthermore, the pyrolysis of biomass also produces gas and char by-products. The gas has high calorific value, representing approximately $13 \mathrm{wt} \%$ of used biomass.

$$
\text { Biomass }+ \text { Energy } \rightarrow \text { Gas }+ \text { Bio-oil }+ \text { Char }
$$

Biomass gasification is the conversion of biomass into a combustible gas mixture with limited oxygen $\left(\mathrm{O}_{2}\right)$ supply at high temperatures, typically in the range of $800-900{ }^{\circ} \mathrm{C}$. Biomass gasification process is typically carried out in a gasifier. There are three types of gasifiers: fixed or moving bed (downdraft and updraft), fluidised bed (bubbling or circulating), and entrained flow gasifier. Gasifiers are categorised based on the contact between the biomass, adsorbent or catalyst with the gasifying agent. In order to improve the quality of the producer gas, various catalyst adsorbents and adsorption processes have been studied. Catalysts such as alkaline earth metal, nickel, and dolomite-based are also used to enhance the reaction. ${ }^{36}$

Gasification process consists of four stages, namely drying, devolatilisation (pyrolysis), oxidation, and reduction processes. ${ }^{50}$ The drying process reduces or eliminates the moisture content of the biomass to about $5 \%$ to $35 \%$ at $100-200^{\circ} \mathrm{C}$. Devolatilisation is the thermal decomposition of biomass in the absence of oxygen or air. This process 
contributes to the reduction of volatile matter and, as a result, hydrocarbon gas is released from the biomass. At sufficiently low temperatures, the hydrocarbon can be condensed into liquid tars. The oxidation process leads to the loss of volatiles from biomass, and is an exothermic process. Thus, the generated product consists mainly of carbon monoxide, hydrogen, and some amount of water at a high temperature (1400 to $1500 \mathrm{~K})$. Those gaseous products are reduced to carbon monoxide and hydrogen by the hot bed charcoal generated during the gasification process, which results in the production of combustible gases such as $\mathrm{CO}, \mathrm{H}_{2}$, and $\mathrm{CH}_{4}$ under endothermic reaction. ${ }^{51}$ Gasification reactions can be presented by the following equations: ${ }^{52}$

$$
\begin{aligned}
& \mathrm{C}+1 / 2 \mathrm{O}_{2} \rightarrow \mathrm{CO} \\
& \mathrm{CO}+1 / 2 \mathrm{O}_{2} \rightarrow \mathrm{CO}_{2} \\
& \mathrm{H}_{2}+1 / 2 \mathrm{O}_{2} \rightarrow \mathrm{H}_{2} \mathrm{O} \\
& \mathrm{CH}_{4}+\mathrm{H}_{2} \mathrm{O} \rightarrow \mathrm{CO}+3 \mathrm{H}_{2}
\end{aligned}
$$

\subsection{Performance of biomass gasification}

Many studies have been done regarding the utilisation of palm oil biomass as fuel for the gasification process and the outcome of results are quite satisfactory. However, researchers are still trying to achieve high performance of biomass gasification technology. The performance could be determined in terms of producer gas composition, heating value of the gas, and gasification efficiency.

With the technology expanding, oil palm biomass such as EFBs, oil palm shell, mesocarp fibre, trunks, and fronds can be utilised as a source of energy. The gasification technology uses biomass to generate hydrogen. Many findings have proved the feasibility of the hydrogen obtained from the biomass gasification as a source of renewable energy, which is able to accommodate almost $50 \%$ of the current hydrogen demands worldwide. ${ }^{53}$

The research by $\mathrm{Li}$ et al. ${ }^{37}$ shows that varying several conditions, such as temperature, steam to biomass ratio, and biomass particle size, may give a significant effect on the gas yield, gas composition, gas low heating value, tar removal, and hydrogen production. At the end of their experiment, the gas yield varied from 1.20 to $8 \mathrm{Nm}^{3} \mathrm{~kg}^{-1}$ biomass, the low heating value (LHV) ranged between 8.85 and $11.98 \mathrm{MJ} \mathrm{Nm}^{-3}$, and the hydrogen yield varied from $50.22 \%$ to $133.25 \%$. The authors also succeeded in developing a tri-metallic catalyst for the gasification process. Approximately $99 \%$ of tar was removed at gasification temperature of $800{ }^{\circ} \mathrm{C}$ by using the developed catalyst and $\mathrm{EFB}$ as a fuel. The catalyst also improved the hydrogen production to above 17 vol\%.
A study by Nipattumakul et al. ${ }^{54}$ examined the syngas characteristics from oil palm trunk waste using steam as the gasifying agent at $800{ }^{\circ} \mathrm{C}$. From their experiment, the trunk waste gasification produced $52.4 \mathrm{~g}$ of syngas yield with $2.86 \mathrm{~g}$ and $685 \mathrm{~kJ}$ of hydrogen and energy yield, respectively. The authors believed that using steam as the gasifying agent may increase the efficiency of hydrogen production. This was supported by Sadaka et al. ${ }^{55}$ and Luo et al. ${ }^{56}$ who claimed that high temperature of oxygen in the air will help to provide the required energy for the burning biomass. High temperature of gasifying agent will help in the devolatilisation process of biomass and producing various gases, thus improving the dry gas yield and carbon conversion efficiency. In addition, high temperature also increases the production of hydrogen and carbon dioxide, since the biomass undergoes a further reaction called the water-gas shift reaction.

Due to high moisture content of oil palm biomass, it seems that palm oil biomass is not practical as a source of fuel, but the research by Kelly-Yong et al. ${ }^{53}$ has overcome this problem by using the supercritical water technology (SCW). Supercritical water is the condition in which the temperature and pressure are above its critical point. At this point, the properties of SCW varied between liquid-like or gas-like condition. The advantage of utilising SCW medium in biomass gasification is that it can deal with the high mois-

\begin{tabular}{|c|c|c|c|c|c|c|c|}
\hline \multirow{2}{*}{$\begin{array}{l}\text { Types of } \\
\text { biomass } \\
\text { residue }\end{array}$} & \multirow{2}{*}{$\begin{array}{l}\text { Lower } \\
\text { heating } \\
\text { value/ } \\
\mathrm{MJ} \mathrm{kg-1}^{-1}\end{array}$} & \multicolumn{5}{|c|}{ Ultimate analysis / wt\% dry basis } & \multirow[t]{2}{*}{ Refs. } \\
\hline & & C & $\mathrm{H}$ & $\mathrm{N}$ & $\mathrm{S}$ & $\mathrm{O}$ & \\
\hline $\begin{array}{l}\text { empty fruit } \\
\text { bunch }\end{array}$ & 18.96 & 48.97 & 7.33 & 0 & 0.68 & 36.3 & 57 \\
\hline $\begin{array}{l}\text { mesocarp } \\
\text { fibres }\end{array}$ & 20.64 & 50.27 & 7.07 & 0.42 & 0.63 & 36.28 & 58 \\
\hline $\begin{array}{l}\text { palm kernel } \\
\text { shells }\end{array}$ & 22.14 & 53.78 & 7.2 & 0 & 0.51 & 36.3 & 53 \\
\hline
\end{tabular}
ture content (>50\%), thus reducing the cost of drying, and making it practical for the palm oil biomass. At high temperatures in supercritical water, the biomass can be converted efficiently, producing high yield of fuel gas rich in hydrogen content. Several investigations have been conducted using the oil palm biomasses in supercritical water gasification, and the results are tabulated in Table 5.

Table 5 - Results of water gasification of oil palm biomass

Although supercritical water gasification has received huge attention due to its ability to extract large amounts of hydrogen, the high activation energy is required to meet the requirement of minimum reaction condition. In addition, inevitable side gaseous mixtures, such as $\mathrm{CO}$ and $\mathrm{CO}_{2}$, also tend to be produced. ${ }^{59}$ Therefore, to overcome these problems, a new enhanced technology has been introduced, called catalytic supercritical water gasification (CSWG). CSWG is a promising technology for production of hydrogen from biomasses with high moisture contents. 
High water temperature and catalyst were incorporated into the process, whereby the concentration of $\mathrm{H}^{+}$and $\mathrm{OH}^{-}$is a good condition for acid- or catalysed reaction. ${ }^{60}$ The structure of water is evolved at high temperature, which leads to the cleavage of hydrogen bonding. As a result, more hydrogen gas (syngas) is produced during the gasification process at high temperature in the presence of water. The catalyst is used to improve the water-gas shift reaction, accelerating the steam reforming, methanation reaction, and cleavage of carbon-oxygen and carbon-carbon chains. ${ }^{60}$ Three types of catalysts are mainly used for gasification technology: alkali metal, transition metal, and activated carbon catalyst. The use of catalysts provides high conversion rate, hydrogen selectivity, and lowers the activation energy in CSWG reaction. ${ }^{59}$ With the development of gasification technology, there is a hope to spark opportunities for commercializing the gasification technology as a green engineering and sustainable energy.

Many more investigations have been conducted by researchers, which show that the palm oil biomass has a bright potential to be utilised for energy generation. Starting in 2009, many Malaysian researchers are encouraged to study the potentiality of utilising oil palm biomass as the precursors in gasification process due to the availability of biomass in Malaysia. ${ }^{61}$ This indicates that Malaysia is preparing to utilise its enormous oil palm biomass. The research of gasification performance is summarised in Table 6 .

\subsection{Challenges in establishment of gasification technology in Malaysia}

Although numerous research activities have been conducted by many institutions in Malaysia on the gasification of palm oil biomass, either in lab, bench- or pilot-scale at different operating conditions, the gasification technologies are not progressing as expected. The understanding of challenges faced by Malaysian palm oil industries is vital to evaluate the sustainability of the gasification technology.

The most contributing factor faced by palm oil biomass industries is the ignorance of the underutilised biomass in oil palm plantations. ${ }^{45}$ Most industries in Malaysia have shown interest only on the production of oil palm without noticing the potential energy conversion from its biomass that can be further explored as promising for energy generation. Some of the oil palm manufacturers have no interest in treating the biomass due to the financial risk. They have to invest in the high initial cost of the gasification technology and wait a long time for the "return of investment", which is why palm oil industries are sceptical in venturing into the gasification technology.

In addition, oil palm biomass has low calorific value due to high moisture content, and, as a result, it is difficult to compact, thus adding to the cost of transportation. The cost would increase if the oil palm plantation is located on the outskirts of a city. ${ }^{64}$ Moreover, the biomass needs to undergo pre-treatment due to high moisture content, which lowers the efficiency of energy conversion. According to the Malaysia Biomass Industries Confederation (MBIC), in order to minimise the cost of energy conversion, the power plant must be located in an approximately $20-30-\mathrm{km}$ radius from the oil palm plantation. On the other hand, pre-treatment of biomass, such as palletising, compacting, drying, and densification, can be implemented to facilitate the thermochemical conversion, as well as logistic management. ${ }^{45}$ Thus, the selection of the best and most cost-effective transportation is vital to mitigate the supply chain risks and reduce the operating cost. ${ }^{47}$

The aforementioned are the factors that are slowing down the gasification technology. To date, no company in Malaysia is generating electricity through gasification at a large scale. Some companies, such as FGV Holdings Berhad, are generating electricity $100 \%$ from the treated EFB via combustion, which is more convenient and less costly than the gasification technology. This power plant is located in Lahad Datu, and produces $10 \mathrm{MW}$ of electricity for the national grid..$^{65}$

With expanding research on the gasification technology, it is anticipated that this technology will be implemented to extract the energy and electricity from the underutilised palm oil biomass in Malaysia. The government should initiate a better policy to encourage investors by providing a conclusive business environment in order to enhance the gasification industry nationwide. This includes conducting workshops for stakeholders, easing the process of obtaining permits, and providing funds and incentives such as Investment Tax Allowance (ITA).

\section{Conclusion}

Energy consumption is expected to hike up in the future. Currently, the main energy source in Malaysia is fossil fuels. However, these non-renewable fuels are not long lasting and will be depleted. Therefore, the derivation of energy from biomass is one of the practical ways in solving this problem. Malaysia is one of the countries in the world that produce a huge amount of oil palm biomass annually. The massive productions of palm oil biomass create huge potential to be converted into the high value-added-products considering their costs, properties, and environmental friendliness. Oil palm biomass can be used to produce a variety of commercial products, such as synthetic biofuels, as well as for power generation. Among all available conversion technologies, gasification can be regarded as an advanced technology that can be commercialised. Data on sustainability proved that using the oil palm biomass to generate energy emits less $\mathrm{CO}_{2}$ emissions due to the characteristics of the feedstock and carbon assimilation. With the best management practice, Malaysia can generate clean energy from biomass gasification and protect the environment at the same time.

\section{ACKNOWLEDGEMENTS}

The authors wish to acknowledge UiTM Cawangan Terengganu Kampus Bukit Besi for financial and technical support. 
Table 6 - Previous studies on utilisation of oil palm biomass for hydrogen production

\begin{tabular}{|c|c|c|c|c|c|c|c|}
\hline Oil palm biomass & Type of gasifier & Catalyst & Operating conditions & G. agent & Scale/type & Product & Refs. \\
\hline kernel shell & fluidised bed & none & $\begin{array}{c}T=600-700{ }^{\circ} \mathrm{C} \\
p=1 \mathrm{~atm}\end{array}$ & air & pilot & $\begin{array}{r}\mathrm{CO}=25-38 \text { vol } \% \\
\mathrm{H}_{2}=15-18 \text { vol } \% \\
\mathrm{O}_{2}=2.02 \text { vol } \%\end{array}$ & 62 \\
\hline kernel shell & fixed bed & none & $\begin{array}{c}T=180{ }^{\circ} \mathrm{C}-260{ }^{\circ} \mathrm{C} \\
p=1 \mathrm{~atm} \\
t=10-70 \mathrm{~min}\end{array}$ & steam & bench & $\begin{array}{r}\mathrm{CO}_{2}=54-62.5 \text { vol\% } \\
\mathrm{H}_{2}=25-33 \text { vol\% } \\
\mathrm{CO}=0.04-0.075 \text { vol\% } \\
\mathrm{CH}_{4}=1-2 \text { vol\% }\end{array}$ & 38 \\
\hline $\begin{array}{c}\text { kernel shell, fibre } \\
\text { and empty fruit } \\
\text { bunch }\end{array}$ & fixed bed & \begin{tabular}{|c|} 
calcine \\
dolomite, \\
nano-NiLaFe
\end{tabular} & $\begin{array}{c}T=750{ }^{\circ} \mathrm{C} \backslash \\
-900{ }^{\circ} \mathrm{C} \\
p=1 \mathrm{~atm}\end{array}$ & steam & bench & $\begin{aligned} \mathrm{H}_{2} & =36.5 \text { vol } \% \\
\mathrm{CO} & =25.8 \text { vol } \% \\
\mathrm{CO}_{2} & =24.5 \text { vol } \% \\
\mathrm{CH}_{4} & =10.2 \text { vol } \%\end{aligned}$ & 37 \\
\hline kernel shell & fixed bed & $\mathrm{Ni} / \mathrm{La} / \mathrm{Al}_{2} \mathrm{O}_{3}$ & $T=900^{\circ} \mathrm{C}$ & air & bench & $\mathrm{H}_{2}=37.28 \mathrm{vol} \%$ & 39 \\
\hline empty fruit bunches & fluidised bed & silica & $\begin{array}{c}T=700-900{ }^{\circ} \mathrm{C} \\
p=1 \mathrm{~atm} \\
\text { particle size }= \\
0.3-0.5 \mathrm{~mm} \\
\mathrm{ER}=0.15^{\circ} 0.35\end{array}$ & air & bench & $\begin{array}{r}\mathrm{H}_{2}=33.9 \mathrm{vol} \% \\
\mathrm{LHV}=15.26 \mathrm{MJ} \mathrm{Nm}^{-3}\end{array}$ & 41 \\
\hline empty fruit bunches & fluidised bed & silica sand & $\begin{array}{c}T=650-1050{ }^{\circ} \mathrm{C} \\
p=1 \mathrm{~atm} \\
\mathrm{ER}=0.17-0.28\end{array}$ & air & pilot & $\begin{array}{r}\mathrm{CH}_{4}=19.24 \text { vol\% } \\
\mathrm{H}_{2}=5.55 \text { vol\% } \\
\mathrm{CO}_{2}=4.31 \text { vol\% } \\
\mathrm{CO}=16.44 \text { vol\% } \\
\mathrm{CCE}=93.5 \% \\
\mathrm{CGE}=72.5 \% \\
\mathrm{HHV}=5.38-5 / 88 \mathrm{MJ} \mathrm{Nm}^{-3}\end{array}$ & 40 \\
\hline fronds & fixed bed & none & $\begin{array}{c}T=700-900{ }^{\circ} \mathrm{C} \\
E R=0.27 \\
\text { rate }=9 \mathrm{~kg} \mathrm{~h}^{-1}\end{array}$ & air & bench & $\begin{array}{r}\mathrm{CO}=22.8-24.9 \text { vol\% } \\
\mathrm{CO}_{2}=11.8-13 \text { vol\% } \\
\mathrm{H}_{2}=8.47-10.53 \mathrm{vol} \% \\
\mathrm{CH}_{4}=2.01-2.03 \mathrm{vol} \% \\
\mathrm{CCE}=74.4-93 \% \\
\mathrm{CGE}=72 \% \\
\mathrm{HHV}=4.5-5.3 \mathrm{MJ} \mathrm{Nm}{ }^{-3}\end{array}$ & 42 \\
\hline fronds & fixed bed & none & $\begin{array}{c}T=700{ }^{\circ} \mathrm{C} \\
\mathrm{ER}=0.35-0.59 \\
p=1 \text { atm }\end{array}$ & air & lab & $\begin{array}{r}\mathrm{CO}=25.3 \text { vol\% } \\
\mathrm{H}_{2}=9.6 \text { vol\% } \\
\mathrm{CO}_{2}=8.21 \text { vol\% } \\
\mathrm{CH}_{4}=1.22 \mathrm{vol} \% \\
\mathrm{LHV}=4.82 \mathrm{MJ} \mathrm{Nm}^{-3} \\
\mathrm{CCE}=92 \%\end{array}$ & 43 \\
\hline empty fruit bunches & fixed bed & none & $\begin{array}{c}T=380{ }^{\circ} \mathrm{C} \\
p=240 \mathrm{bar} \\
t=8-32 \mathrm{~min} \\
\mathrm{ER}=0.3-0.5\end{array}$ & steam & lab & $\begin{array}{r}\mathrm{H}_{2}=59.0 \text { vol\% } \\
\mathrm{CO}=2.31 \text { vol\% } \\
\mathrm{CO}_{2}=24.0 \text { vol\% } \\
\mathrm{CH}_{4}=0.6 \text { vol } \%\end{array}$ & 27 \\
\hline empty fruit bunches & fluidised bed & none & $\begin{array}{c}T=700{ }^{\circ} \mathrm{C} \\
p=25.53 \text { bar }\end{array}$ & steam & modelling & $\begin{aligned} \mathrm{H}_{2} & =71.12 \mathrm{~mol} \% \\
\mathrm{CO} & =1.413 \mathrm{~mol} \% \\
\mathrm{CO}_{2} & =25.01 \mathrm{~mol} \% \\
\mathrm{CH}_{4} & =1.52 \mathrm{~mol} \%\end{aligned}$ & 1 \\
\hline kernel shell & fluidised bed & $\begin{array}{c}\mathrm{CaO} \\
\text { adsorbent }\end{array}$ & $\begin{array}{l}T=675^{\circ} \mathrm{C} \\
p=1 \mathrm{~atm}\end{array}$ & steam & bench & $\mathrm{H}_{2}=80.40$ vol $\%$ & 63 \\
\hline kernel shell & fixed bed & $\begin{array}{l}\mathrm{CaO} \\
\text { adsorbent, } \\
\text { coal ash }\end{array}$ & $\begin{array}{c}T=650-750{ }^{\circ} \mathrm{C} \\
\text { Particle size }= \\
0.25-0.5 \mathrm{~mm}\end{array}$ & steam & lab & $\begin{array}{r}\mathrm{H}_{2}=36.61 \text { vol\% } \\
\mathrm{CO}=24.75 \text { vol\% } \\
\mathrm{CO}_{2}=1.42 \text { vol\% } \\
\mathrm{CH}_{4}=37.32 \text { vol } \%\end{array}$ & 46 \\
\hline
\end{tabular}




\section{Literatura \\ References}

1. S. Langè, L. A. Pellegrini, Economic analysis of a combined production ofhydrogen-energy from empty fruit bunches, Biomass Bioenergy 59 (2013) 520-531, doi: https://doi. org/10.1016/j.biombioe.2013.08.039.

2. Statistical Review of World Energy, URL: www.bp.com/statisticalreview.

3. S. Lim, L. K. Teong, Recent trends, opportunities and challenges of biodiesel in Malaysia: an overview, Renew. Sustain. Energy Rev. 14 (2010) 938-954, doi: https://doi. org/10.1016/j.rser.2009.10.027.

4. H. C. Ong, T. M. I. Mahlia, H. H. Masjuki, A review on energy scenario and sustainable energy in Malaysia, Renew. Sustain. Energy Rev. 15 (2011) 639-647, doi: https://doi. org/10.1016/j.rser.2010.09.043.

5. M. A. A. Mohammed, A. Salmiaton, W. W. Azlina, M. S. M. Amran, Gasification of oil palm empty fruit bunches: A characterization and kinetic study, Bioresour. Technol. 110 (2012) 628-636, doi: https://doi.org/10.1016/j.biortech.2012.01.056.

6. S. Oberthür, H. E. Ott, The Kyoto Protocol: international climate policy for the $21^{\text {st }}$ century, Springer Science \& Business Media, Heidelberg/Berlin, 1999.

7. M. P. O. Board, A summary on the performance of the Malaysian oil palm industry. (2007).

8. A. S. Baharuddin, L. S. Hock, M. Z. Yusof, N. A. A. Rahman, U. K. Shah, M. A. Hassan, M. Wakisaka, K. Sakai, Y. Shirai, Effects of palm oil mill effluent (POME) anaerobic sludge from $500 \mathrm{~m}^{3}$ of closed anaerobic methane digested tank on pressed-shredded empty fruit bunch (EFB) composting process, African J. Biotechnol. 9 (2010) 2427-2436, url: https:// www.ajol.info/index.php/ajb/article/view/78478/68833.

9. S. H. Shuit, K. T. Tan, K. T. Lee, A. H. Kamaruddin, Oil palm biomass as a sustainable energy source: A Malaysian case study, Energy 34 (2009) 1225-1235, doi: https://doi. org/10.1016/j.energy.2009.05.008.

10. S. Prasertsan, P. Prasertsan. Biomass residues from palm oil mills in thailand: an overview on quantity and potential usage, Biomass Bioenergy 1 (1996) 34-37, doi: https://doi. org/10.1016/S0961-9534(96)00034-7.

11. N. Soltani, A. Bahrami, M. I. Pech-Canul, L. A. González, Review on the physicochemical treatments of rice husk for production of advanced materials, Chem. Eng. J. 264 (2015) 899-935, doi: https://doi.org/10.1016/j.cej.2014.11.056.

12. P. Fatemeh Rupani, R. Pratap Singh, M. Hakimi Ibrahim, N. Esa, Review of current palm oil mill effluent (POME) treatment methods: Vermicomposting as a sustainable practice, World Appl. Sci. J. 11 (2010) 70-81, url: https://citeseerx.ist.psu.edu/ viewdoc/download?doi=10.1.1.390.5998\&rep=rep1\&type $=$ pdf

13. National Biomass Strategy 2020: New wealth creation for Malaysia's palm oil industry, Agensi Inovasi Malaysia, Kuala Lumpur, Malaysia, 2011, url: https://renewable-carbon.eu/ news/media/news-images/20111121-08/National Biomass Strategy_Nov_2011_FINAL.pdf.

14. F. Boons, A. Mendoza, Constructing sustainable palm oil: how actors define sustainability. J. Clean. Prod. 18 (2010) 16861695, doi: https://doi.org/10.1016/j.jclepro.2010.07.003.

15. S. Binti, A. Mahat, The palm oil industry from the perspective of sustainable development: A case study of Malaysian palm oil industry, in proceedings Binti2012ThePO, Grad. Sch. Asia Pacific Stud. Ritsumeikan Asia Pacific Univ., Japan, 2012.
16. B. G. Dompok, Deepening Malaysia's palm oil advantage, Econ. Transform. Program. a roadmap Malaysia (1 Malaysia), 2013.

17. R. Dungani, P. Aditiawati, S. Aprilia, K. Yuniarti, T. Karliati, IC. Suwandhi, I. Sumardi, Biomaterial from oil palm waste: properties, characterization and applications, Palm Oil, Viduranga Waisundara, IntechOpen, 2018, doi: https://doi. org/10.5772/intechopen.76412.

18. J. Sahari, M. A. Maleque, Mechanical Properties of Oil Palm Shell Composites, Int. J. Polym. Sci. 2016 (2016) Article ID 7457506, 7 pages, doi: https://doi. org/10.1155/2016/7457506.

19. O. A. Hassan, M. Ishida, I. M. Shukri, Z. A. Tajuddin, Oil-palm fronds as a roughage feed source for ruminants in Malaysia, Food and Fertilizer Technology Center for the Asian and Pacific Region, Publications (1994) 1-8, url: https://www.fftc. org.tw/htmlarea_file/library/20110729161002/eb420.pdf.

20. O. Sulaiman, N. Salim, N. A. Nordin, R. Hashim, M. Ibrahim, M. Sato, The potential of oil palm trunk biomass as an alternative source for compressed wood, BioRes. 7 (2012) 26882706, doi: https://doi.org/10.15376/biores.7.2.2688-2706.

21. Z. Ahmad, H. M. Saman, P. M. Tahir, Oil Palm Trunk Fiber as a Bio-Waste Resource for Concrete Reinforcement, Int. J. Mech. Mater. Eng. 5 (2010) 199-207.

22. W. R. W. Daud, K. N. Law, Oil palm fibers as papermaking material: Potentials and challenges, BioRes. 6 (2011) 901917, doi: https://doi.org/10.15376/biores.6.1.901-917.

23. P. Ndayishimiye, M. Tazerout, Use of palm oil-based biofuel in the internal combustion engines: performance and emissions characteristics, Energy 36 (2011) 1790-1796d, doi: https://doi.org/10.1016/j.energy.2010.12.046.

24. A. B. Nasrin, A. N. Ma, Y. M. Choo, S. Mohamad, M. H.Rohaya, A. Azali, Z. Zainal, Oil palm biomass as potential substitution raw materials for commercial biomass briquettes production, Am. J. Appl. Sci. 5 (2008) 179-183, doi: https:// thescipub.com/pdf/ajassp.2008.179.183.pdf.

25. R. Hashim, W. N. A. W. Nadhari, O. Sulaiman, F. Kawamura, S. Hiziroglu, M. Sato, T. Sugimoto, T. G. Seng, R. Tanaka, Characterization of raw materials and manufactured binderless particleboard from oil palm biomass, Mater. Des. 32 (2011) 246-254, doi: https://doi.org/10.1016/j.matdes.2010.05.059.

26. H. P. S. A. Khalil, M. R. N. Fazita, A. H. Bhat, M. Jawaid, N. A. N. Fuad, Development and material properties of new hybrid plywood from oil palm biomass, Mater. Des. 31 (2010) 417424, doi: https://doi.org/10.1016/j.matdes.2009.05.040.

27. M. A. Hassan, L.-N. Yee, P. L. Yee, H. Ariffin, A. R. Raha, Y. Shirai, K. Sudesh, Sustainable production of polyhydroxyalkanoates from renewable oil-palm biomass, Biomass Bioenergy 50 (2013) 1-9, doi: https://doi.org/10.1016/j.biombioe.2012.10.014.

28. L.-L. Chai, S. Zakaria, C. H. H. Chia, S. H. Nabihah, R. Rasid, Physico-mechanical properties of PF composite board from EFB fibres using liquefaction technique, Iran. Polym. J. 18 (11) (2009) 917-923, url: https://www.sid.ir/en/journal/ ViewPaper.aspx?id=163521.

29. H. A. Hassim, M. Lourenço, G. Goel, B. Vlaeminck, Y. M. Goh, V. Fievez, Effect of different inclusion levels of oil palm fronds on in vitro rumen fermentation pattern, fatty acid metabolism and apparent biohydrogenation of linoleic and linolenic acid, Anim. Feed Sci. Technol. 162 (2010) 155-158, doi: https://doi.org/10.1016/j.anifeedsci.2010.09.011.

30. S. Sabiha-Hanim, A. M. Siti-Norsafurah, Physical properties of hemicellulose films from sugarcane bagasse, Procedia Eng. 42 (2012) 1390-1395, doi: https://doi.org/10.1016/j. 
proeng.2012.07.532.

31. T. Ahmad, M. Rafatullah, A. Ghazali, O. Sulaiman, R. Hashim, Oil palm biomass-Based adsorbents for the removal of water pollutants - A review, J. Environ. Sci. Heal. Part C 29 (2011) 177-222, doi: https://doi.org/10.1080/10590501.2011.601 847.

32. M. R. Zakaria, S. Hirata, M. A. Hassan, Hydrothermal pretreatment enhanced enzymatic hydrolysis and glucose production from oil palm biomass, Bioresour. Technol. 176 (2015) 142-148, doi: https://doi.org/10.1016/j.biortech.2014.11.027

33. Z. Nahrul Hayawin, A. A. Astimar, I. M. Hakimi, W. H. W. Hasamudin, H. P. S. A. Khalil, Vermicomposting of different types of oil palm fibre waste using Eudrilus eugeniae: A comparative study, J. Oil Palm Res. 23 (2011) 979-989, url: http://jopr.mpob.gov.my/vermicomposting-of-different-types-of-oil-palm-fibre-waste-using-eudrilus-eugeniae-a-comparative-study/.

34. C. S. Tucker, J. A. Hargreaves, Environmental best management practices for aquaculture, John Wiley \& Sons, 2009, doi: https://doi.org/10.1002/9780813818672.

35. K. T. Tan, K. T. Lee, A. R. Mohamed, S. Bhatia, Palm oil: addressing issues and towards sustainable development, Renew. Sustain. Energy Rev. 13 (2009) 420-427, doi: https:// doi.org/10.1016/j.rser.2007.10.001.

36. D. Sutton, B. Kelleher, J. R. H. Ross, Review of literature on catalysts for biomass gasification, Fuel Process. Technol. 73 (2001) 155-173, doi: https://doi.org/10.1016/S03783820(01)00208-9.

37. J. Li, Y. Yin, X. Zhang, J. Liu, R. Yan, Hydrogen-rich gas production by steam gasification of palm oil wastes over supported tri-metallic catalyst, Int. J. Hydrogen Energy 34 (2009) 91089115, doi: https://doi.org/10.1016/j.ijhydene.2009.09.030.

38. C. W. Kean, J. N. Sahu, W. M. A. W. Daud, Hydrothermal gasification of palm shell biomass for synthesis of hydrogen fuel, BioRes. 8 (2013) 1831-1840, doi: https://doi.org/10.15376/ biores.8.2.1831-1840.

39. H. Yang, R.Yan, H. Chen, D. H. Lee, D. T. Liang, C. Zheng, Pyrolysis of palm oil wastes for enhanced production of hydrogen rich gases, Fuel Process. Technol. 87(2006) 935-942, doi: https://doi.org/10.1016/j.fuproc.2006.07.001.

40. P. Lahijani, Z. A. Zainal, Gasification of palm empty fruit bunch in a bubbling fluidized bed: a performance and agglomeration study, Bioresour. Technol. 102 (2011) 20682076, doi: https://doi.org/10.1016/j.biortech.2010.09.101.

41. M. A. A. Mohammed, A. Salmiaton, W. A. K. G. Wan Azlina, M. S. Mohammad Amran, A. Fakhru'l-Razi, Y. H. Taufiq-Yap, Hydrogen rich gas from oil palm biomass as a potential source of renewable energy in Malaysia, Renew. Sustain. Energy Rev. 15 (2011) 1258-1270, doi: https://doi.org/10.1016/j. rser.2010.10.003.

42. F. M. Guangul, S. A. Sulaiman, A. Ramli, Gasifier selection, design and gasification of oil palm fronds with preheated and unheated gasifying air. in Bioresource Technology, vol. 126, Elsevier Ltd, 2012, pp. 224-232, doi: https://doi. org/10.1016/j.biortech.2012.09.018.

43. S. M. Atnaw, S. A. Sulaiman, S. Yusup, Syngas production from downdraft gasification of oil palm fronds, Energy 61 (2013) 491-501, doi: https://doi.org/10.1016/j.energy.2013.09.039.

44. S. Sivasangar, Z. Zainal, A. Salmiaton, Y. H. Taufiq-Yap, Supercritical water gasification of empty fruit bunches from oil palm for hydrogen production, Fuel 143 (2015) 563-569, doi: https://doi.org/10.1016/j.fuel.2014.11.073.
45. Y. H. Chan, K. W. Cheah, B. S. How, A. C. MinhLoy, M. Shahbaz, H. K. G. Singh, N. R. Yusuf, A. F. A. Shuhaili, S. Yusup, W. A. W. A. K. Ghani, J. Rambli, Y. Kansha, Ho. Lo. Lam, B. H. Hong, S. Li. Ngan, An overview of biomass thermochemical conversion technologies in Malaysia, Sci. Total Environ. 680 (2019) 105-123, doi: https://doi.org/10.1016/j.scitotenv.2019.04.211

46. M. Shahbaz, S. Yusup, A. Inayat, D. O. Patrick, A. Pratama, M. Ammar, Optimization of hydrogen and syngas production from PKS gasification by using coal bottom ash, Bioresour. Technol. 241 (2017) 284-295, doi: https://doi. org/10.1016/j.biortech.2017.05.119.

47. B. S. How, K. Y. Tan, H. L. Lam, Transportation decision tool for optimisation of integrated biomass flow with vehicle capacity constraints, J. Clean. Prod. 136 (2016) 197-223, doi: https://doi.org/10.1016/j.jclepro.2016.05.142.

48. W. A. Wan Ab Karim Ghani, R. A. Moghadam, M. A. Salleh, A. B. Alias, Air gasification of agricultural waste in a fluidized bed gasifier: hydrogen production performance, Energies $\mathbf{2}$ (2009) 258-268, doi: https://doi.org/10.3390/en20200258.

49. M. S. M. Zaini, S. S. A. Syed Hassan, Methane Adsorption Performance of the Palm Kernel Shell-Derived Carbon Material Activated Using $\mathrm{CO}_{2}$-Steam Sequential Combination, Malaysian J. Anal. Sci. 20 (2016) 1390-1397, doi: https:// doi.org/10.17576/mjas-2016-2006-18.

50. M. Puig-Arnavat, J. C. Bruno, A. Coronas, Review and analysis of biomass gasification models, Renew. Sustain. Energy Rev. 14 (2010) 2841-2851, doi: https://doi.org/10.1016/j. rser.2010.07.030.

51. A. R. Shivakumar, S. N. Jayaram, S. C. Rajshekar, N. Delhi, Inventory of existing technologies on biomass gasification, Karnataka State Counc. Scuience Technol. New Delhi, 2008.

52. K. Motylinski, M. Blesznowski, M. Skrzypkiewicz, M. Wierzbicki, A. Zurawska, A. Baran, M. Bakala, J. Kupecki, Analysis of Soot Deposition Mechanisms on Nickel-Based Anodes of SOFCs in Single-Cell and Stack Environment, Processes 8 (2020) 1370, doi: https://doi.org/10.3390/pr8111370.

53. T. L. Kelly-Yong, K. T. Lee, A. R. Mohamed, S. Bhatia, Potential of hydrogen from oil palm biomass as a source of renewable energy worldwide, Energy Policy 35 (2007) 5692-5701, doi: https://doi.org/10.1016/j.enpol.2007.06.017.

54. N. Nipattummakul, I. I. Ahmed, S. Kerdsuwan, A. K. Gupta, Steam gasification of oil palm trunk waste for clean syngas production, Appl. Energy 92 (2012) 778-782, doi. https:// doi.org/10.1016/j.apenergy.2011.08.026.

55. D. S. Sadaka, Gasification": Iowa State University 1521 West F. Ave. Nevada, IA 50201, (1998).

56. S. Luo, B. Xiao, Z. Hu, S. Liu, X. Guo, M. He, Hydrogen-rich gas from catalytic steam gasification of biomass in a fixed bed reactor: Influence of temperature and steam on gasification performance, Int. J. Hydrogen Energy 34 (2009) 2191-2194, doi: https://doi.org/10.1016/j.ijhydene.2008.12.075.

57. M. S. Umikalsom, A. B. Ariff, H. S. Zulkifli, C. C.Tong, M. A. Hassan, M. I. A. Karim, The treatment of oil palm empty fruit bunch fibre for subsequent use as substrate for cellulase production by Chaetomium globosum Kunze. Bioresour. Technol. 62 (1997) 1-9, doi: https://doi.org/10.1016/S09608524(97)00132-6.

58. S. Salètes, F. A. Siregar, J.-P. Caliman, T. Liwang, Ligno-cellulose composting: Case study on monitoring oil palm residuals, Compost Sci. Util. 12 (2004) 372-382, doi: https://doi. org/10.1080/1065657X.2004.10702207.

59. Y. Guo, S. Z. Wang, D. H. Xu, Y. M. Gong, H. H. Ma, X. Y. Tang, Review of catalytic supercritical water gasification for 
hydrogen production from biomass, Renew. Sustain. Energy Rev. 14 (2010) 334-343, doi: https://doi.org/10.1016/j. rser.2009.08.012.

60. M. S. Mastuli, N. Kamarulzaman, M. F. Kasim, S. Sivasangar, M. I. Saiman, Y. H. Taufiq-Yapa, Catalytic gasification of oil palm frond biomass in supercritical water using $\mathrm{MgO}$ supported $\mathrm{Ni}, \mathrm{Cu}$ and $\mathrm{Zn}$ oxides as catalysts for hydrogen production, Int. J. Hydrogen Energy 42 (2017) 11215-11228, doi: https://doi.org/10.1016/j.ijhydene.2017.02.174.

61. E. Onoja, S. Chandren, F. I. A. Razak, N. A. Mahat, R. A. Wahab, Oil palm (Elaeis guineensis) biomass in Malaysia: the present and future prospects, Waste Biomass Valoriz. 10 (2019) 2099-2117, doi: https://doi.org/10.1007/s12649018-0258-1.

62. V. S. Chok, A. Gorin, S. Yusup, Palm Shell Gasification in Pi- lot Scale Compartmented Fluidized Bed Gasifier: Premilinary High Temperature Performance and Challenges, 2009, url: http://www.malrep.uum.edu.my/rep/Record/my.utp. eprints.1269/Details.

63. J. H. Matthys, Masonry: components to assemblages. (ASTM, 1990), doi: https://doi.org/10.1520/STP1063-EB.

64. A. Ismail, M. A. Simeh, M. M. Noor, The production cost of oil palm fresh fruit bunches: the case of independent smallholders in Johor, Oil Palm Ind. Econ. J. 3 (2003) 1-7, url: http://palmoilis.mpob.gov.my/publications/OPIEJ/opiejv3n1-1.pdf.

65. FGV Holdings Berhad. FGV to Boost Returns from Renewable Energy Projects, URL: https://www.fgvholdings.com/ press release/fgv-to-boost-returns-from-renewable-energy-projects/.

\section{SAŽETAK}

\section{Preliminarna studija održivosti biomase uljane palme kao sirovine: izvedba i izazovi tehnologije rasplinjavanja u Maleziji \\ Mohd Saufi Md Zaini ${ }^{\mathrm{a}^{*}}$ i Mohd Jumain Jalil ${ }^{\mathrm{b}}$}

Prekomjerna uporaba energije na globalnoj razini potaknula je svijest o pronalasku novih, čistih izvora energije. Malezija ima velike resurse uljane palme te je velik potencijal da se njezina biomasa upotrebljava kao sirovina za rasplinjavanje u Maleziji. lako mnoge institucije u Maleziji provode brojna istraživanja, tehnologije rasplinjavanja ne pokazuju željeni napredak. Razumijevanje potencijala koji ima biomasa uljane palme kao i izazova s kojima se suočava malezijska industrija od vitalnog su značaja za procjenu izvedivosti tehnologije rasplinjavanja temeljenog na biomasi uljane palme u ovoj državi.

\section{Ključne riječi}

Staklenički plinovi, biomasa uljane palme, održivost, izazov, tehnologija rasplinjavanja,

pretvorba energije

a School of Chemical Engineering, College of Engineering, Universiti Teknologi MARA, Cawangan Terengganu, Kampus Bukit Besi, 23200 Dungun, Terengganu, Malezija

${ }^{\mathrm{b}}$ School of Chemical Engineering, College of Engineering, Universiti Teknologi MARA, Cawangan Pulau Pinang, 13500 Permatang Pauh, Pulau Pinang, Malezija
Pregledni rad

Prispjelo 1. prosinca 2020. Prihvaćeno 25. siječnja 2021. 